\title{
The Urban Landscape in the Graphic Representations of the Cathedral of Palermo
}

\author{
By Starlight Vattano*
}

\begin{abstract}
This study proposes some reflections on the relationship between the Cathedral of Palermo and the urban portion where it is placed, in relation to the indissoluble connection with the landscape that in the history offered a variety of perceptive suggestions marked by the passage and the coexistence of different cultural and social domination. To this end, the multiscale historical-urban planning analysis puts in place the role that territorial and urban morphology has had over time in relation to the Cathedral of Palermo. In this sense, the relationship between the architectural artefacts, such as the Royal Palace and the Town Hall, and the urban context is studied according to its access routes, from the Phoenician domination to the nineteenth century configuration, through the examination of graphic studies on the Arab-Norman city, on the first cartographies of 16th century, up to the representations of Gaetano Lossieux of 1818. The cartographic analysis and the elaboration of an orographic model provide images of the historical stratification of Palermo's urban texture. The objective is to highlight how the perception of the building changed together with the landscape and urban modifications through the integration of the $3 d$ model of the Cathedral within the urban digital model.
\end{abstract}

\section{Introduction}

In the 8th century $\mathrm{BC}$, the orographic configuration of the area where the city of Palermo arose, appeared to the Phoenicians as a large hollow to the sea, surrounded by mountains.

Later, enclosed by that mountainous curtain, Monreale was founded, as you can see in the 17th century bird's-eye engravings where the two cities, seen from the sea, were linked through the Stradone aligned with the two gates of the city (Porta Nuova and Porta Felice).

Through a cross-sectional and intertwined study between historical cartography and digital reconstruction of the terrain, it is possible to read those morphological features that have fostered urban transformations over time, defining the physiognomy of Palermo.

Graphic analysis, carried out through the development of digital models based on historical cartography and bird's-eye views, made by travelers over the centuries, provides the occasion to read the volumetric transformations determining different configurations of the Cathedral of Palermo due to the culture and the necessities of time.

This study illustrates a graphic telling on the urban modification through images, digital models and graphic interpretations of terrain characteristics affecting the current urban form.

*Assistant Professor, University of Palermo, Italy. 
The aim is to reconstruct the most significant architectural and urban moments of the Palermo's Cathedral with its context, pursuing a reflection linked to the close link between architecture and landscape and directing particular attention to the morphological and territorial conformations graphically described and transmitted by travelers, through their perception, in a dynamic visual tale.

The historical periods considered for the elaboration of digital models include the Phoenician (VII century BC), Arab (831-1072) and Norman (1072-1194) dominations, the 16th century city and the nineteenth-century expansion. During the iconographic collection on the Cathedral of Palermo, some drawings made by the Grand Tour travelers have been selected.

These travelers, driven by the curiosity of knowing Mediterranean places, provided graphic and literary descriptions through which it was possible to show changes and traces of history on the architectural artifact.

The identification of the journey made by travelers who portrayed the city has been the key to the graphic restitution methodology used to make new images, taking into account the perception and recognizability of the elements characterizing the Cathedral.

The combination between historical data (cartographies, bird's-eye views, architectural details) and digital model provides an iconographic synthesis tracing the spatial positioning of the points of view chosen for the drawings by establishing a chronological and perceptual parallelism.

\section{The Cartography of Palermo. Graphic Reflections}

Over time the Pellegrino, Gallo, Castellaccio, Cuccio and Grifone Mountains have been the background of bird-eye views and manuscripts maps portraying a city surrounded by walls.

Some of the first cartographies of Palermo show a rectangular matrix city in a close relationship between the urban parts within the walls and the extra moenia areas. Taking into account the main objective of this study, namely the reconstruction of the historical moment that defined the contemporary configuration of Palermo and its urban relation with the Cathedral, some of the most emblematic historical cartographies have been considered. The graphic representations that will follow are selected according to the main urban evolution phases of the city together with the architectural modifications of the Cathedral. In 1699, a cartography made by L. de Villamage, provides a more complete reading system than to the previous cartographies, particularly in the graphic representation of the three-dimensional development of the rock curtain over the predominantly flat orographic surface (Figure 1). 


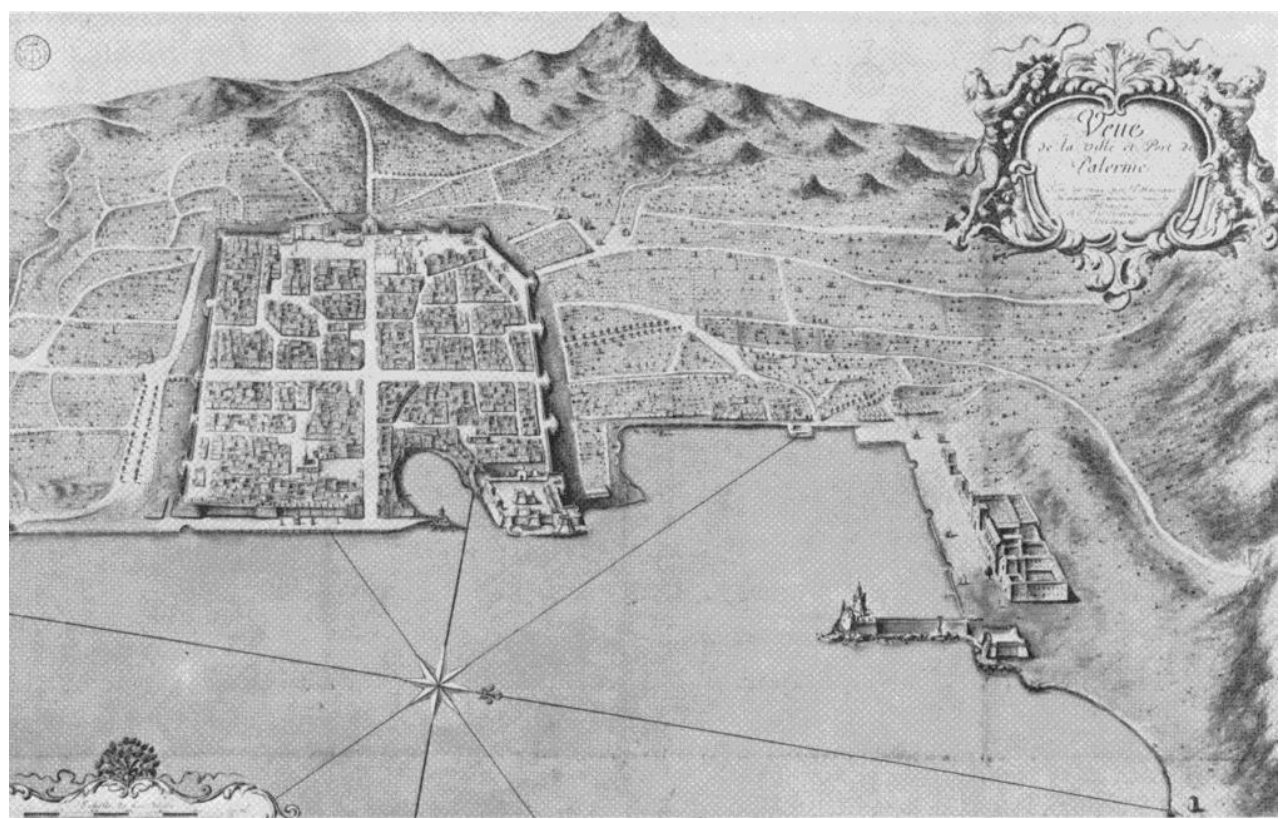

Figure 1. Bird's-eye View Made by Villamage in 1699

The cartographies illustrating Palermo dating from 1580 to the end of the sixteenth century show a graphic and geometric matrix of the urban texture placed inside the wall, strongly inspired by the one made by Natale Bonifazio in 1580 . According to De Seta and Di Mauro ${ }^{1}$ it will be the type of urban representation adopted in the following years (Figure 2).

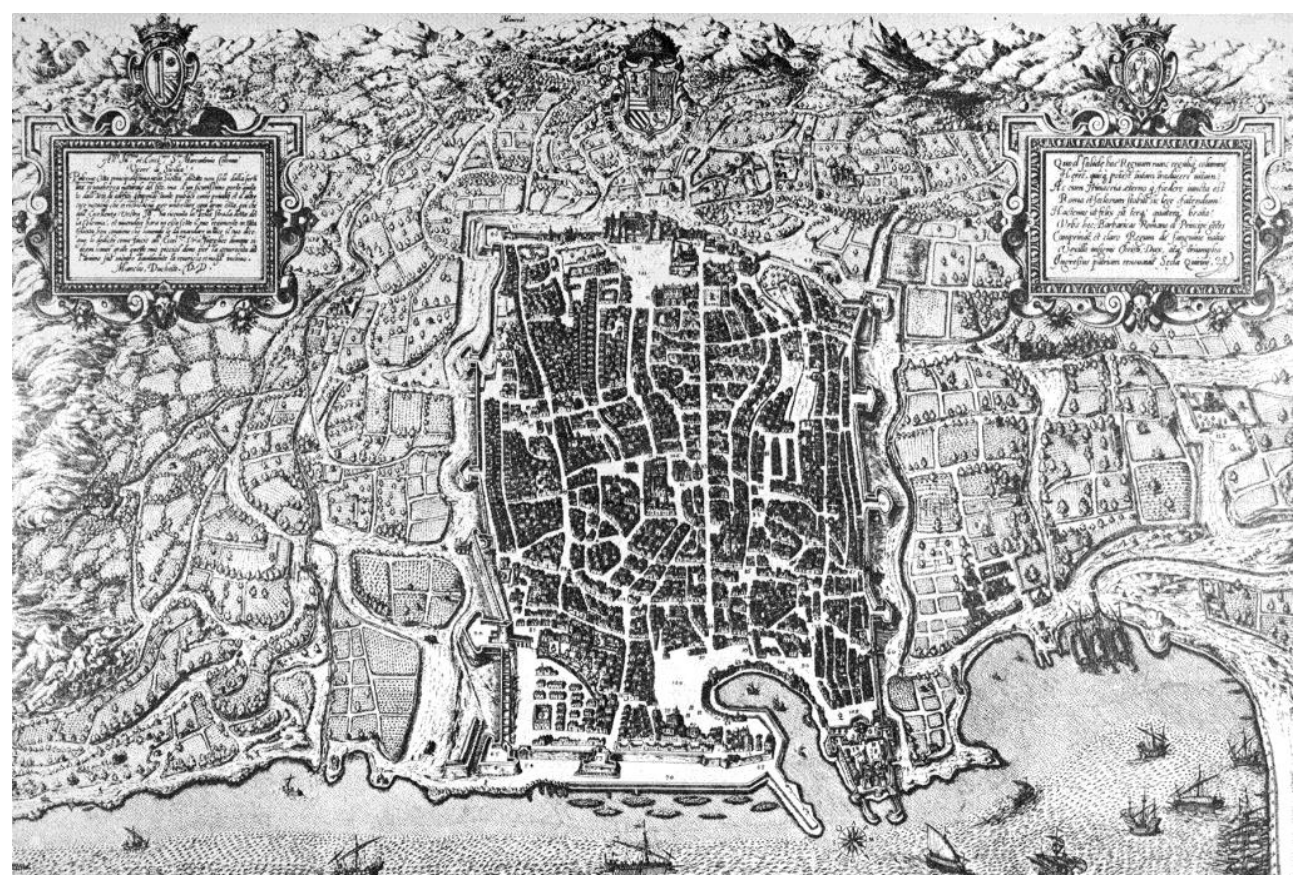

Figure 2. Plan of Palermo Drawn by Natale Bonifazio in 1580. In the Foreground the Cut of the Ancient Cassaro Crossing the City

1. C. De Seta and L. Di Mauro, Le città nella storia d'Italia (Bari: Editori Laterza, 1981). 
The change of the city's orientation, according to a graphic point of view is both a redefinition of the urban and geometric role of Cassaro, a rectilinear axis cutting the city into two parts, the main element of the urban texture in the following cartographies until the early nineteenth century.

In these representations, the urban herringbone design, more evident in the sixteenth-century plan made by Braun and Hogenberg, will be particularly visible comparing to the former nucleus precisely for the strong sign made by Cassaro's track line, which, through its geometric rigor, further marks the texture of narrow streets and interior courtyards of ancient Palermo.

Still hardly legible, the trace of the two rivers, Kemonia and Papireto, will be described graphically only starting from the cartography made by Domenico Campolo in $1726 .^{2}$

An anonymous drawing of 1686, Palermo el antiguo, shows how the territorial morphology of the site affected the urban expansion by the development of the rivers naturally producing two portions, one between the two streams, identifiable by the walls erected along them, where the Phoenician city and subsequently the Arab and Norman power centers settled. The other portion of territory, beyond the rivers, is the area where the city of Palermo expanded in the following centuries (Figure 3).

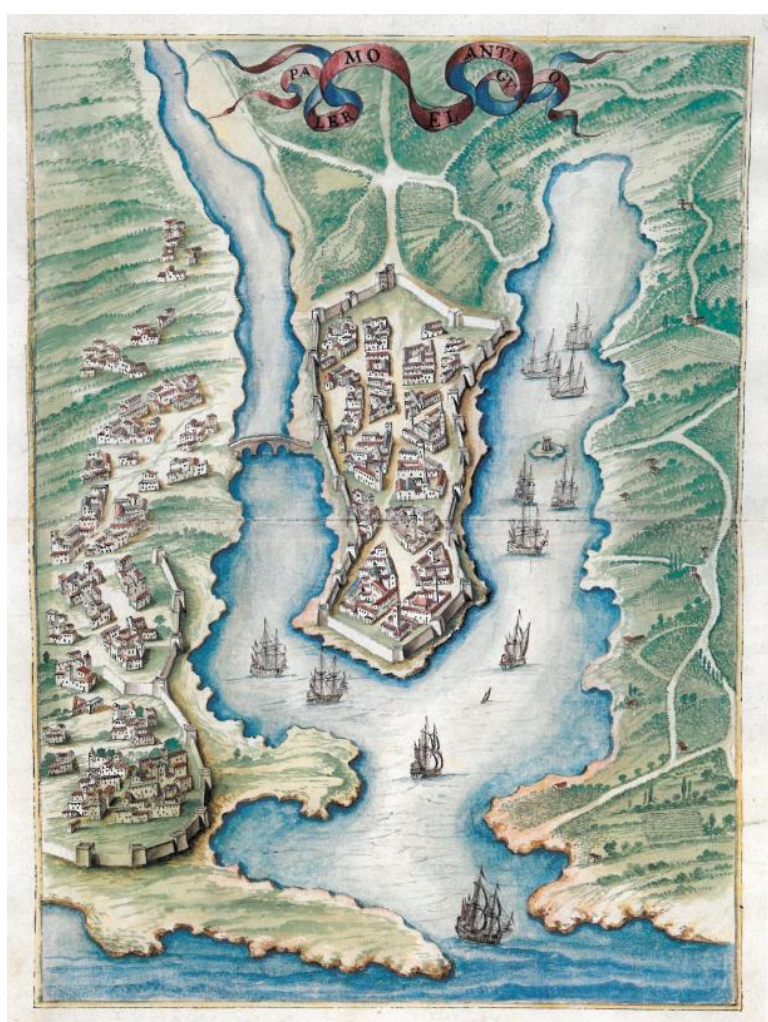

Figure 3. Anonymous, Palermo el antiguo, Topographic Interpretation of the Old Nucleus of Palermo Made in 1686

2. Domenico Campolo, in 1926, drawn a cartography of the city of Palermo to identify the areas affected by the earthquake, recognizing neighborhoods with major damages at the two rivers. 
Therefore, the strip of land in this representation facilitates the historical reading of stratifications by the identification of the ancient Palepoli and its expansion by Neapoli. ${ }^{3}$ It provides an idea of the ancient city of Panormos and at the same time, the area where the Cathedral was erected later. Although the next urban development filled the two river beds, it is possible to read the Phoenician imprint and river development in the cartographic representations after the eighteenth century, where it is also graphically evident the cutting of streets designed in the last years of the 16th century identifying the four districts of Palermo inside the walls (Figure 4).

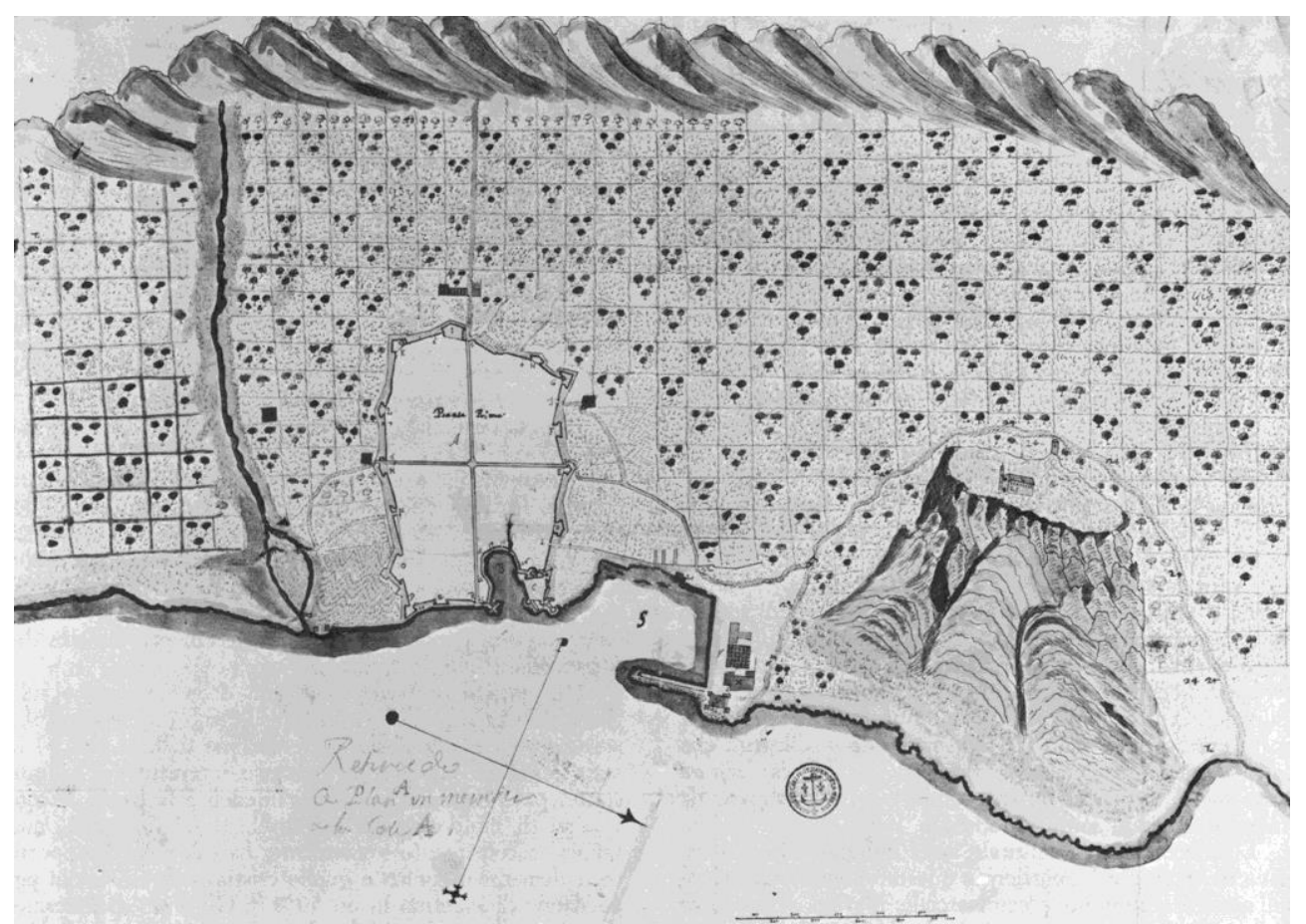

Figure 4. Cartography of the Seventeenth Century Highlighting the Urban Layout of Palermo

In this regard, a 17th century plan depicts an abstract drawing where the city's quadrilateral is revealed without the dense urban texture, through a morphological contrast determined between the natural configuration of the area outside the walls and the four districts recognizable by the intra moenia cutting streets.

From the 1713, through the image of the city made by Hermil and Giuseppe Ghibert, in addition to the crossing of Cassaro and Via Maqueda with the opening of the Strada Nuova, the urban layout is defined in relation to a detailed graphic description of the extra mural areas. Two interesting representations of Palermo of the eighteenth century illustrate the urban fabric with the cut of streets and walls bounding the layout developed in height.

The former cartography called Plano de la ciudad de Palermo, made by

3. The ancient Palepoli corresponded with the original nucleus of the city closed into the Arab walls. The further expansion took the name of Neapoli. These nuclei constituted the Cassaro, from the arab al-Qasr. 
Gaetano Lazzara in 1703 (Figure 5) and the latter of 1726 made by Antonino Bova and published by Antonio Mongitore (Figure 6) to document the damage caused by the earthquake of the 1725 .

Lazzara drawn the view with much more details in elevation, from the relationship between the height of the Cathedral and surrounding buildings.

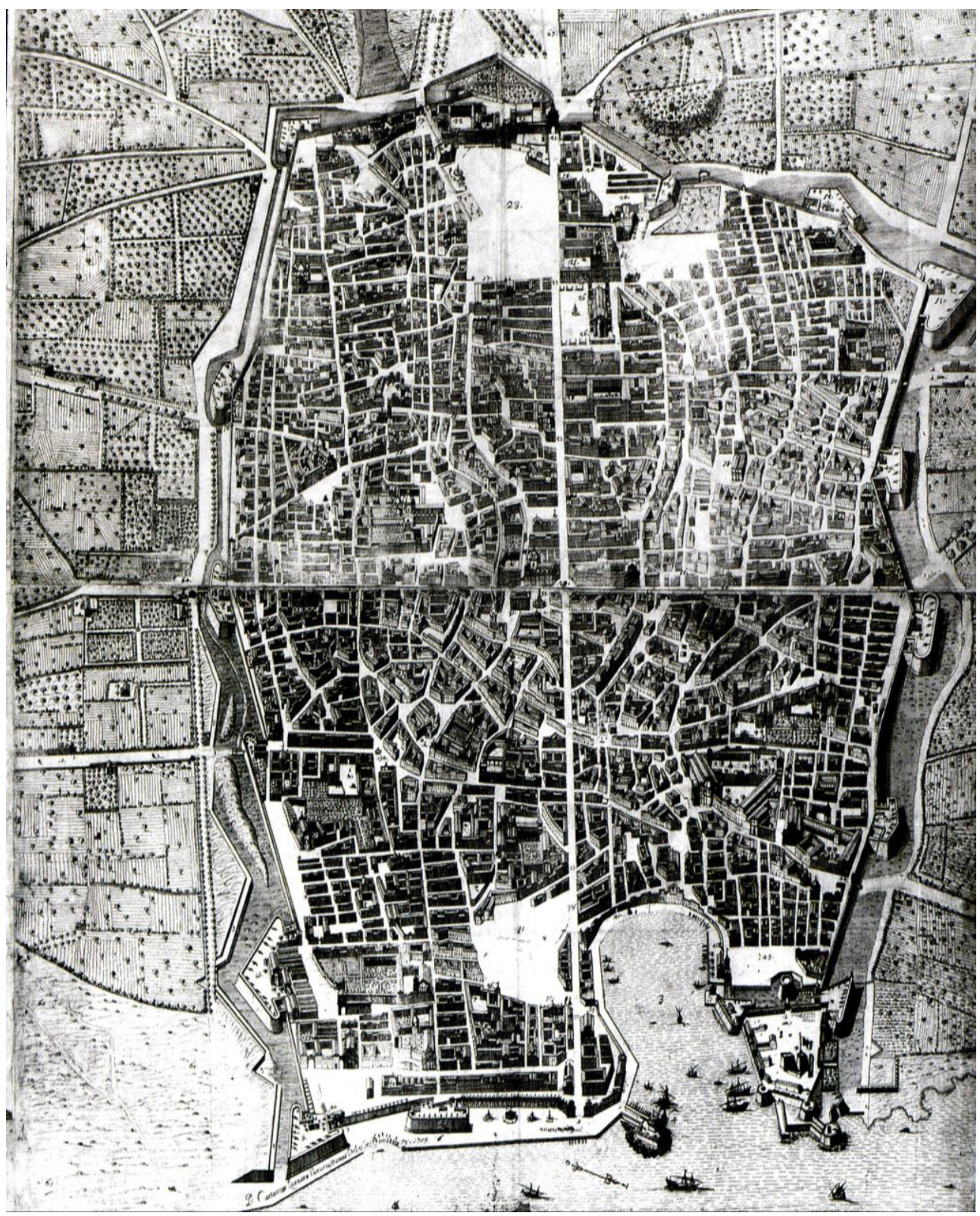

Figure 5. Plano de la Ciudad de Palermo, Axonometric View of the City Made by Gaetano Lazzara in 1703 


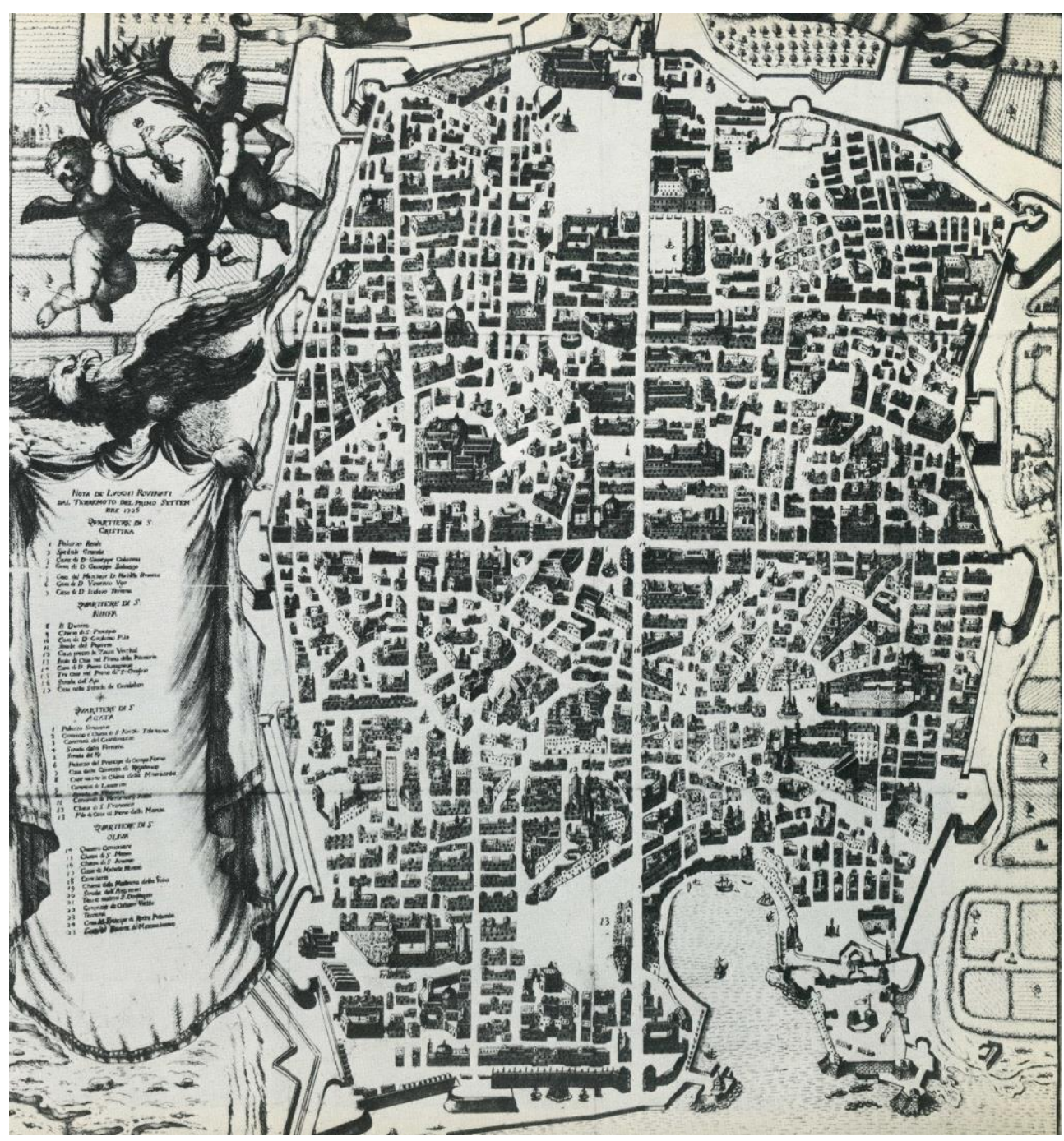

Figure 6. Plan of Palermo Engraved by Antonino Bova Published in 1727 by Antonio Mongitore Documenting Earthquake's Damages of the Previous Year

A significant plan of 1777 drawn by the Marquis of Villabianca shows particular attention to the territorial morphology as you can see by the method of representation, which he uses to distinguish the bands of the urban texture corresponding to the riverbeds. Indeed, Villabianca highlights an architectural and spatial difference between the three urban portions, which allow to recognize in the cartography the presence of the rivers, with a chromatic diversification to read the city in a transversal way. The two-dimensionality of the plan interfaces with the orographic complexity of the territory through a simple imaginary gesture of "historical layers" of the urban system (Figure 7). Furthermore, the analytical process of identification of the urban parts of the city (the ancient nucleus, the city within the river's track and the neighborhood outside), distinguishes the city's design giving information also about the city's expansion out of the walls. Finally, Gaetano Lossieux in 1818 drawn the most significant plan of the 19th century, which constituted the reference for subsequent urban representations. 


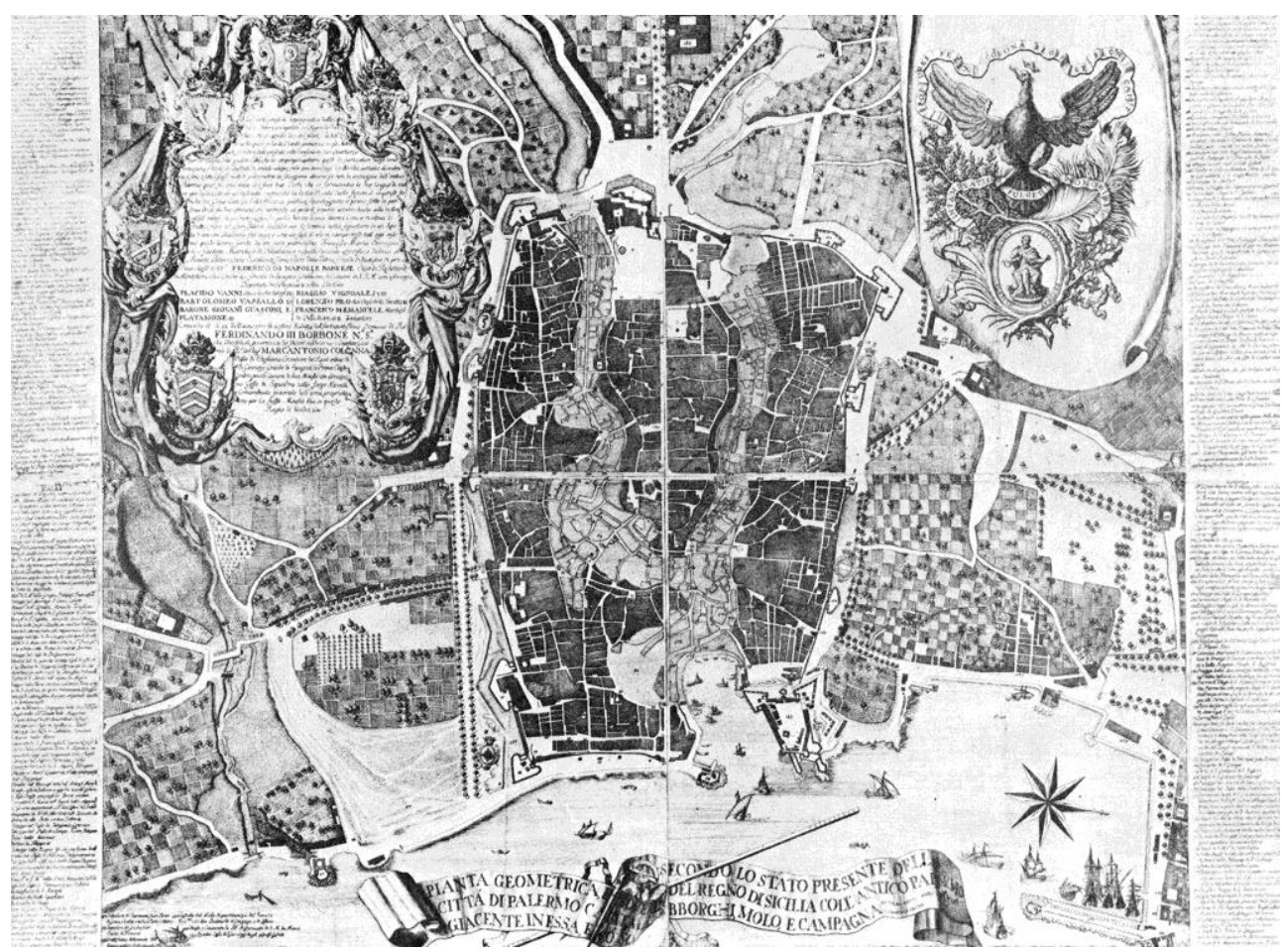

Figure 7. The Plan of Palermo Drawn by the Marquis of Villabianca in 1777 Highlights the Riverbeds of Kemonia and Papireto

The Cathedral of Palermo in the Historic Cartography

The study of historical cartographies shows how the process of urban expansion, from the Phoenician settlement, has been strongly influenced by the morphological conditions of the site. In fact, the orographic layout of the Punic city identifies the location of Neapolis, which occupies the space of the hill between the Palepolis and the sea, in the VI century BC.

Urban transformations, identified through cartographic representation, show some elements of urban fabric easily recognizable since the Arab-Norman period. As already said, the primal nucleus of Palepolis incorporated a portion of territory including the site where the Cathedral arose with the expansion of Neapolis, by the reconstruction of G. M. Columba of 1910.

Through several hypotheses of urban configuration, he demonstrates the strategic and architectural role of the three most important buildings in Palermo, the Royal Palace, the Cathedral and the Town Hall, inside the walls together with the city's oldest nucleus (Figure 8).

One can appreciate the relationship between the body of the Cathedral and the surrounding urban fabric starting from the cartography of Bonifazio of 1580 (Figure 2), where pseudo-axonometric view provides a three-dimensional value to the position of the Chatedral although the height development of the surrounding buildings is not reliable.

Despite this, the representation provides the dimensional ratio between the space occupied by the Cathedral and the other buildings, emphasized by the backward movement of the architectural body that leaves space to the churchyard. 


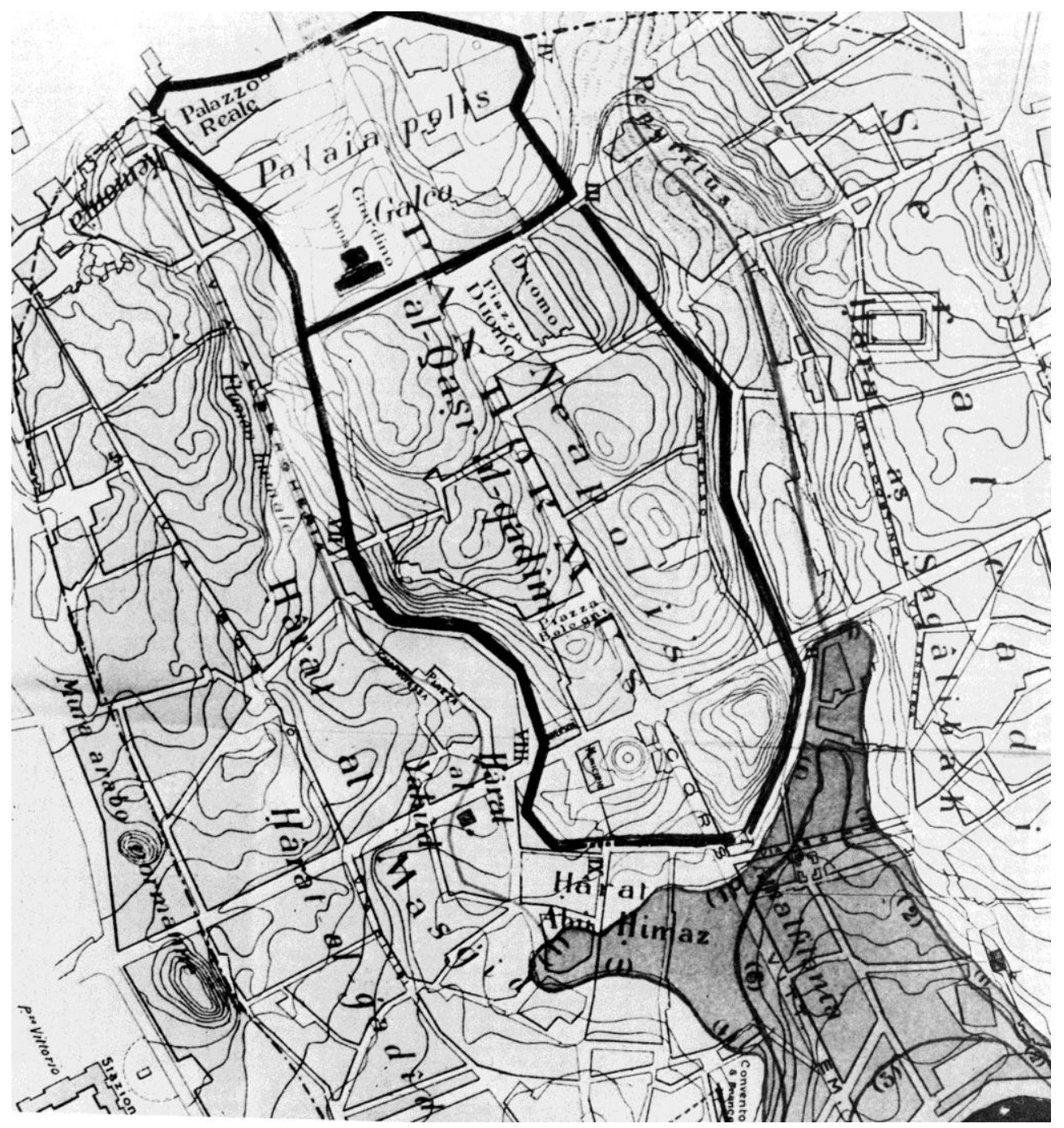

Figure 8. Reconstruction of the VI Century BC of the Palermo's Old Nucleus. The Neapolis is between the Palepolis and the Sea (by Columba 1920)

This urban sign is legible also in the cartography published subsequently, such as that drawn by Matteo Florimi in 1580, Braun, Hogenberg, and Mario Cartaro in 1581, thanks to the orientation of Palermo, tracked with a rectilinear axis crossing it.

This axis, called Stradone, led to Monreale's abbey and at the same time, constitutes a strong graphic sign of urban configuration along which other buildings are aligned (Figure 9).

According to Bellafiore, between the 17 th and 18th centuries, «scholars [...] conjectured without any documentary support the existence of three previous churches: the former of the first century, the second of 330 and the latter of 592603.» ${ }^{4}$ In addition, regarding the area where the great mosque arose, Bellafiore asserts that the Cathedral occupied only a part specifically within the Neapoli, near

4. G. Bellafiore, La cattedrale di Palermo (Palermo: S. F. Flaccovio Editore, 1999), 13. 
the wall that separated it from the Palepoli determining its orientation. ${ }^{5}$

Add to this, the similarity between the Halqah, corresponding to the Palepolis, the nucleus on the hillside touched by the two rivers and the other Islamic citadels. In both cases, the monarch and the political power lived in harmonious combination with the green, according to the descriptions of Arab travelers who told a city articulated by tortuous courtyards and alleys.

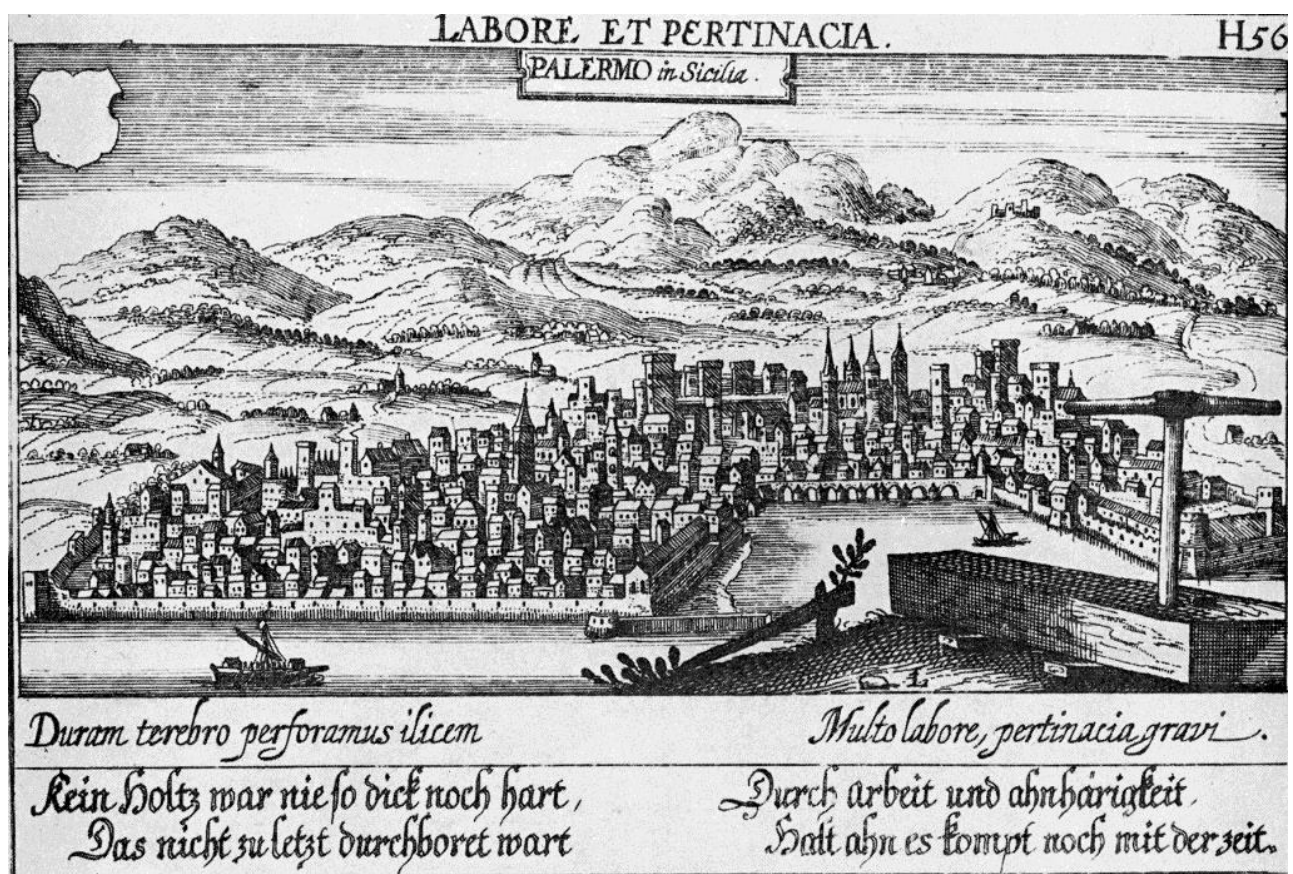

Figure 9. View of the City of Palermo of 1581 Inspired to the Analogue Published in the Work of G. Braun and F. Hogenberg

The Cathedral faced with the palace of power and the other districts of Cassaro, it appaired as surrounded by a massive walled courtyard and intertwined by numerous storehouse, baths and shops constituting the second part of the Arab city. The presence of the low buildings surrounding the palace and the Cathedral meant that the visitor had a complete view of the architectural body, appreciating both the formal composition and contextualization in the landscape. On the other hand, the Cathedral, since its origins, responded both to the worship and fortitude functions, along with that preeminent one of funeral temple reserved for the monarchs, retaining the vocation possessed in the Islamic age of a large mosque serving the ancient, merchant and directional nucleus of the city.

Regarding the relationship between the Cathedral and the orographic condition of the site where the original large mosque was built, the architectural body is to be conceived not as an isolated construction but as a key element of urban and landscape interventions, together with the organic layout of Palermo, before the Ruggero's throne in 1130 and later during the development of the Norman monarchy.

5. For further study see F. Calamia F. and A. Catalano, La cattedrale di Palermo. Otto secoli di vicende architettoniche (Palermo: Epos, 1981), 10. 
By focusing on the perceptive impact that the Cathedral should have to the traveler of that period, Ibn Jobair tells «At the entrance of the palace we walked beneath a covered porch without interruption until we came to a church of immense mass. We were told the porch serves as passage for the king when he comes to this temple». ${ }^{6}$ You have to relate the imposing volume of this great "temple" to the narrow space of the covered path, which allowed the king to reach the Cathedral directly from the palace. ${ }^{7}$ This kind of spatial complementarity accentuated the perception of the "immense mass" of the Cathedral.

It should be noted that the size reached by the city of Palermo during the Arab domination in the 11th century, characterized the urban layout until the mideighteenth century, although only in the sixteenth century the urban image of the city known in the modern age will be composed.

\section{The Cathedral of Grand Tour. Digital Hybridization}

The observation of the representations of Palermo and the Cathedral, allows tracing a series of graphic elements describing the morphological condition of the site, the urban structure and the relationship between the Cathedral and the city.

The views of Tiburzio Spannocchi depict the mountainous curtain enclosing Palermo, no longer represented by the sea but from Mount Pellegrino, in continuity with the flat portion of the conca d'oro where the city lies. Between these two areas, there are the buildings of the sixteenth-century, from which the Cathedral bell towers stand out, with material austerity and rigid volume, almost in contrast to the intricate urban plot where it insists (Figure 10).

Some views of Camillo Camilliani portray the city by the sea highlighting the perspective relationship between the urban part overlooking to the Norman palace and the Cathedral of Monreale, inserted in its morphological context.

In this way, Camilliani emphasizes the role of the mountainous curtain that encloses the city, compared to the Spannocchi representations.

Continuing the reading of the views that depict the Cathedral into its urban context, in 1677, Gabriele Merelli draws the trace of the Stradone, which from Porta Felice led to Monreale's abbey.

6. Cf. M. Amari, Biblioteca arabo-sicula (Torino e Roma: 1880-1881, I), 159.

7. We can make a comparison with the Via Coperta (covered street) of the Andalusian city of Cordoba built to allow caliphs to reach the Mosque from their palace, as you read in De Seta and Di Mauro, Le città nella storia d'Italia (Bari: Editori Laterza, 1981), 37. 


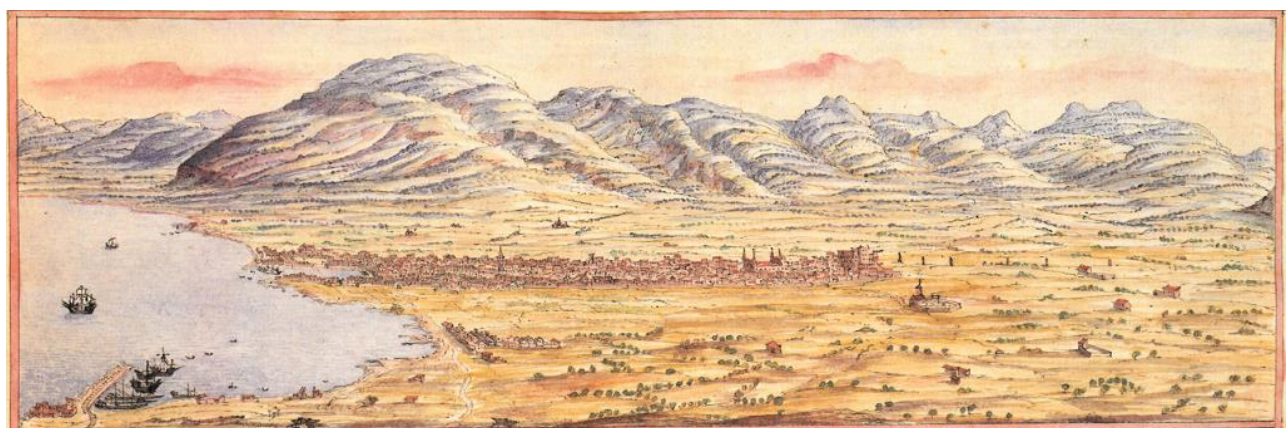

Figure 10. Drawing by Tiburzio Spannocchi, Palermo retratto da Monte Pellegrino, 1578

The vertical sign of the bells towers of both Cathedrals accentuates this link more (Figure 11).

In this context of cartographic analysis, it is interesting to focus on a perspective view of Palermo in 1581, showing the city seen from the sea in the Aragonese period. This drawing gives a different volumetric value to the Cathedral with respect to the building contexts, although it is not a probable representation from a dimensional point of view. The Cathedral is portrayed in a decentralized position, considering instead barycentric the Norman palace.

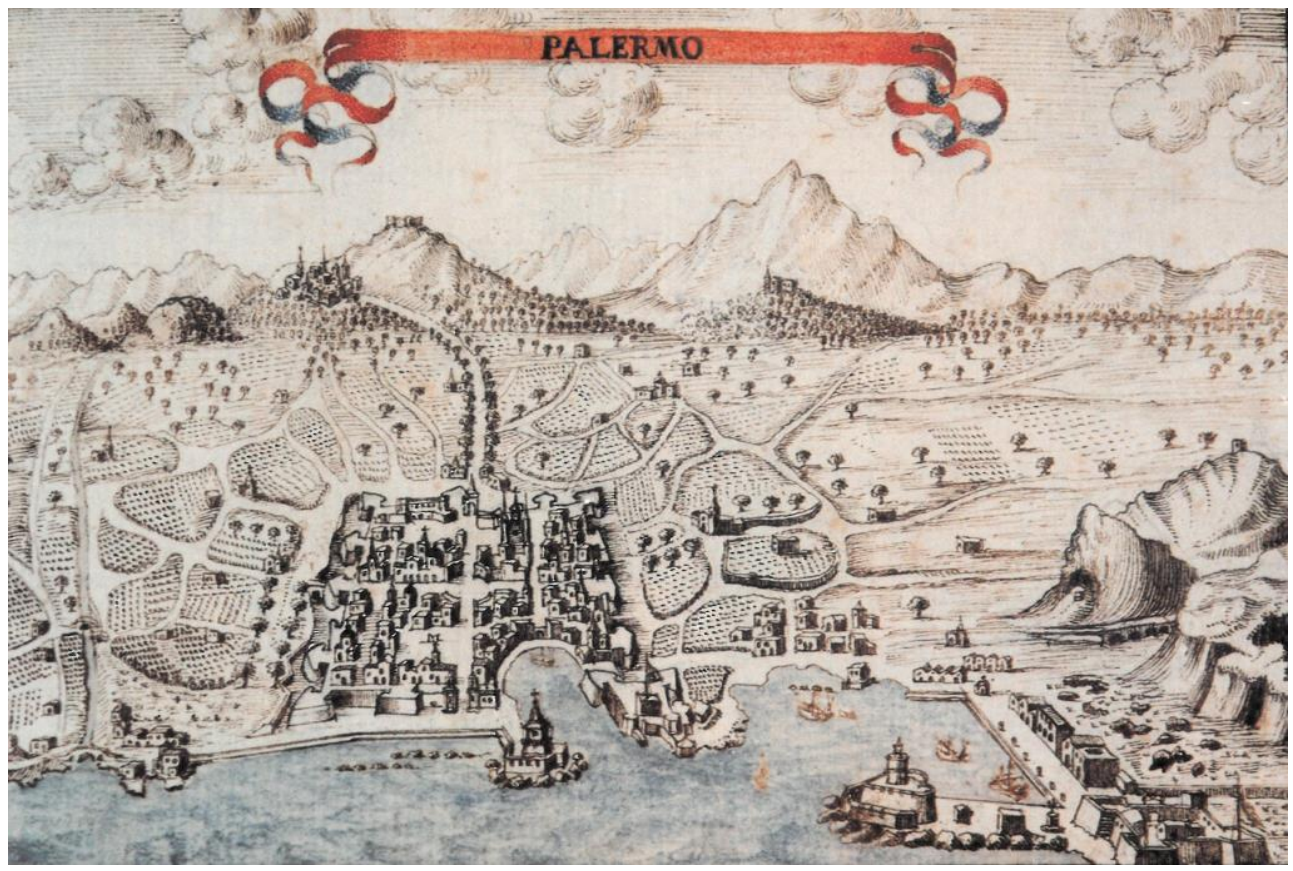

Figure 11. Cartography of Palermo by G. Merelli, Palermo, 1677

In 1837, Francesco Zerilli, remarking scrupulously the volumetric relationships between the buildings of Palermo in the nineteenth-century, portrays a panoramic view of the city from on top of Porta Nuova.

In this representation, the Cathedral dialogues with the two lateral extremities of the drawing constituted by Mount Pellegrino and Capo Zafferano, connected by the line of the sea, which becomes the element of graphic equilibrium of the 
composition (Figure 12).

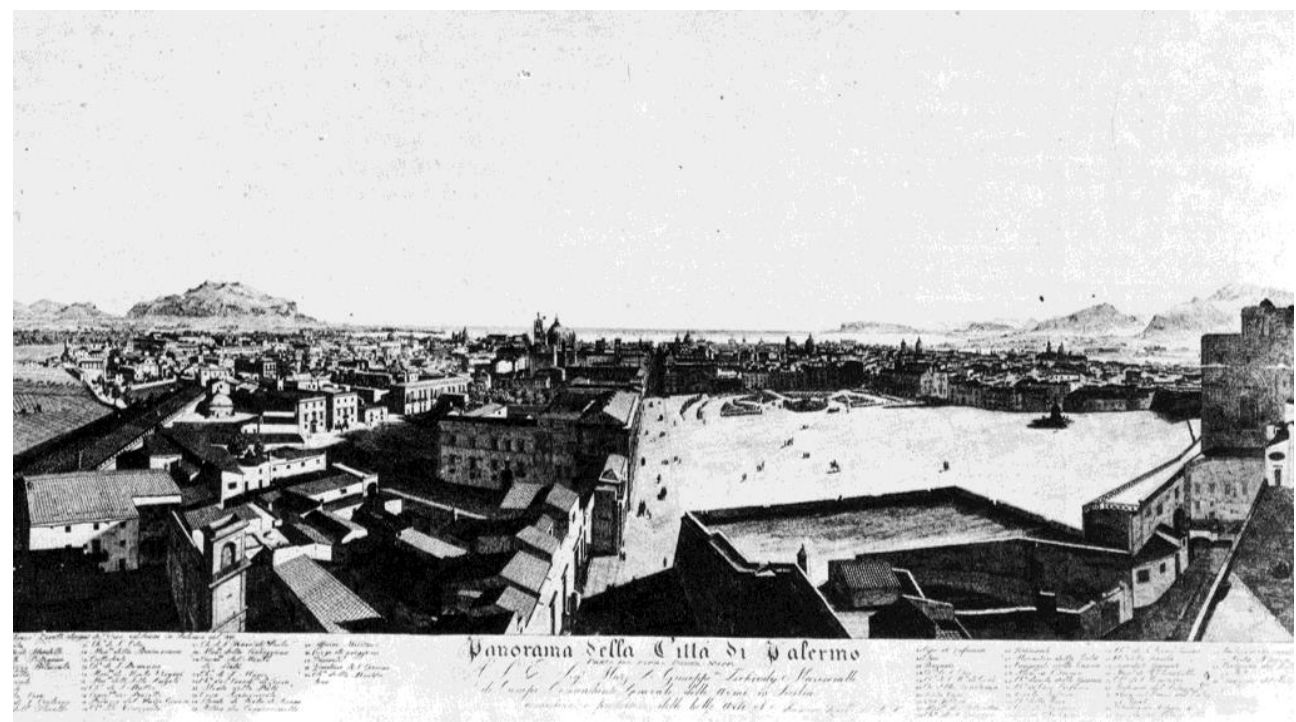

Figure 12. View of the City of Palermo from Porta Nuova by Francesco Zerilli in 1837

You can recognize such morphological correspondence in a lithography of 1844 published in L'Italie à vol d'oiseau, ou Histoire et description sommaires des principales villes de cette contrée by Étienne Hippolyte. He represents the city from an imaginary point of view identifying the three great elements of the urban physiognomy: the Norman palace, the Cathedral and Mount Pellegrino (Figure $13)$.

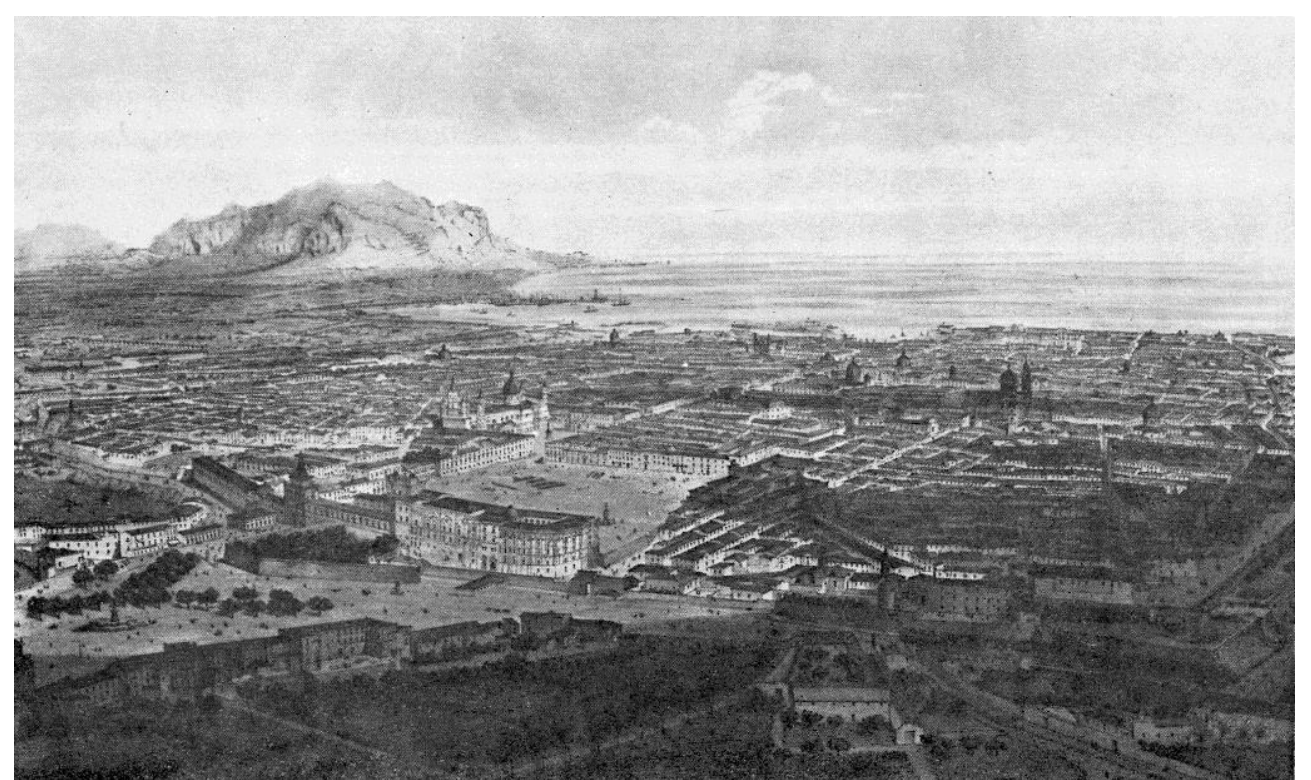

Figure 13. Litography of 1844 Edited in Etiennez Hippolyte, L'Italie à vol d'oiseau, ou Histoire et description sommaires des principales villes de cette contrée 
Now, focusing on the idea of an "itinerary" inside the city, it is shown how travelers perceived, during the centuries, the great mass of the Cathedral. For this reason, some of the representations made between the eighteenth and early twentieth century have been considered.

Most of the perspective views portraying the Cathedral from three points of view: towards the apses from Sett'Angeli square, towards the southern elevation, at the ancient Cassaro, with the front square and towards Via Matteo Bonello, at the western elevation.

Jakob Ignaz Hittorf tells the Cathedral from this last point of view, dividing the perspective frame into three parts and occupying almost one-third the two pointed arches connecting the Cathedral to the adjacent Archbishop's Palace (Figure 14).

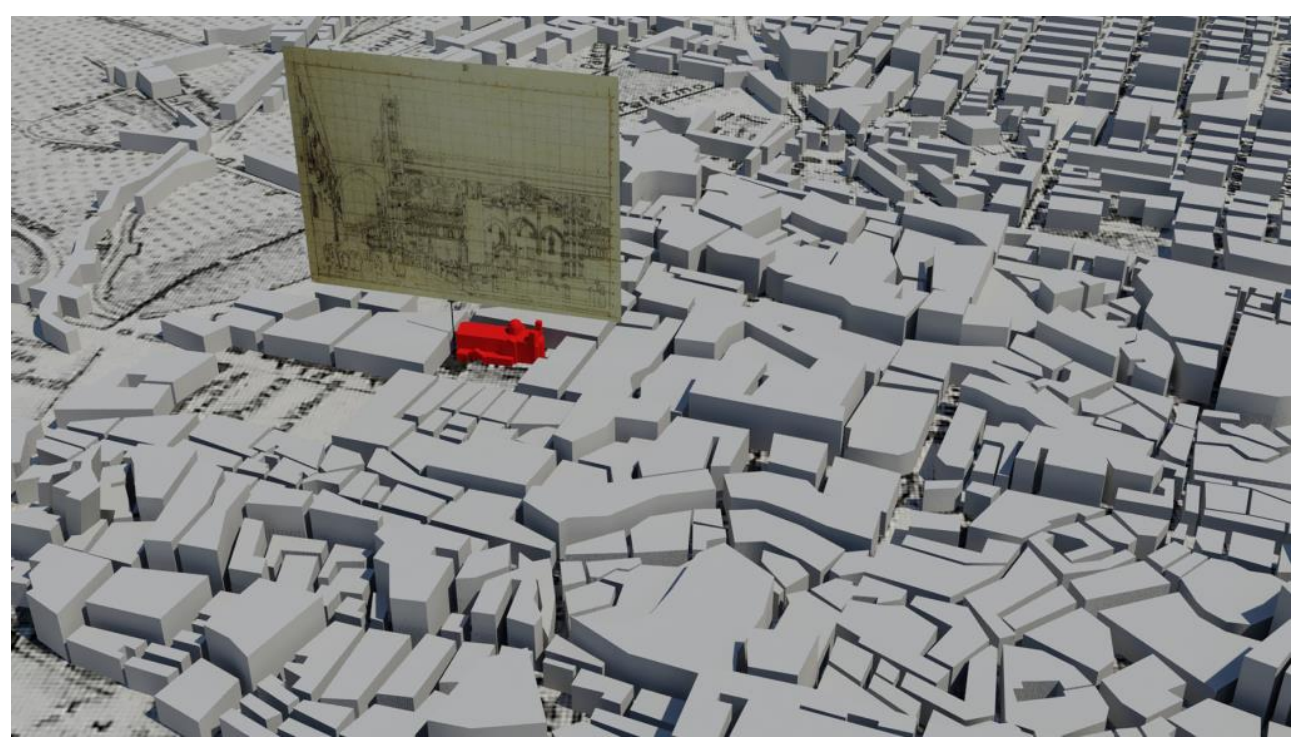

Figure 14. View of the Cathedral of Palermo by Jakob Ignaz Hittorf Inserted in the Digital Model of the Historic Center of Palermo (Model and Digital Elaboration by $S$. Vattano)

Theodore Duclère draws a view of the apses depicting the scale ratio between the imposing volume expressing the whole Cathedral's mass gravity and the urban void generated by Sett'Angeli square, connected with the ancient Cassaro.

The curvature of the apses is also remarked by the geometry of the marble tarsies describing its plastic physiognomy (Figure 15).

In 1761, Antonino Bova made an engraving of the southern elevation of the Cathedral before the eighteenth century transformations, which once again let itself be read in its architectural stratifications revealing the passage of time through the traces of the ethnic groups who dominated the ancient Panormo (Figure 16). 


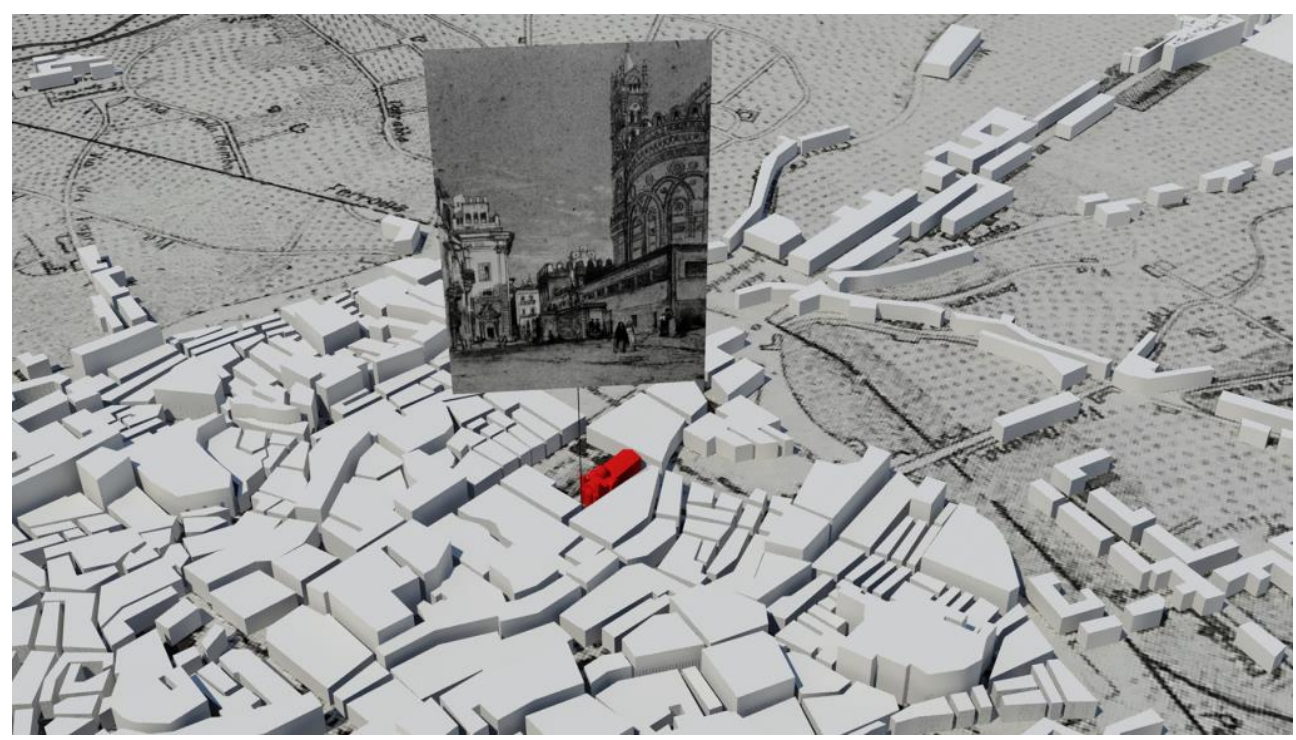

Figure 15. Drawing by Theodore Duclère of the Cathedral Portrayed from the Apses at Sett'Angeli Square Inserted in the Digital Model of the Historic Center of Palermo (Model and Digital Elaboration by S. Vattano)

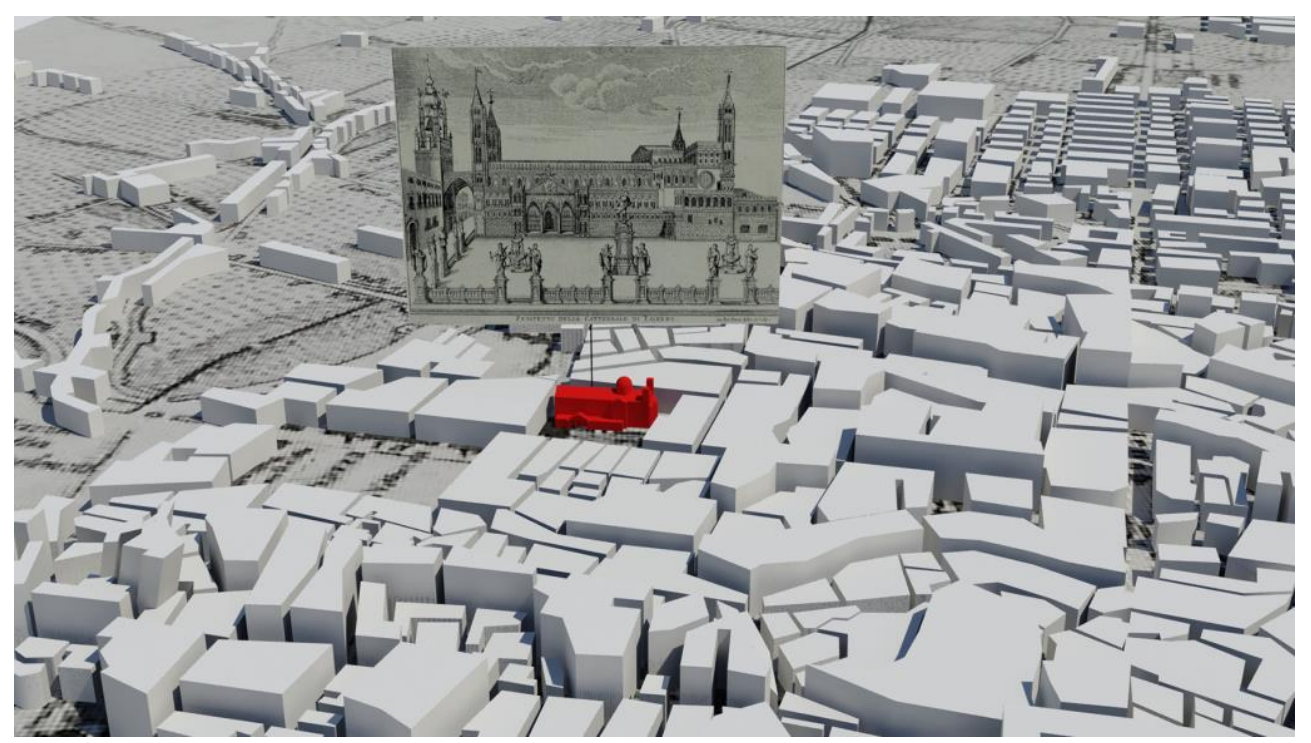

Figure 16. Engraving by Antonino Bova of 1761 of the Southern Elevation of the Cathedral Inserted in the Digital Model of the Historic Center of Palermo (Model and Digital Elaboration by $S$. Vattano)

The views of the Cathedral illustrating the evolution of the great architectural artefacts in relation to the site morphological nature, the landscape, and the sea, together with its location within the dense urban layout provide a reading key for the "travel story" through images. We are talking about a sort of hybridization between two forms of reality's representation, on the one hand the engraving, the life drawing, the relationship between architectural artefacts/perception/graphic translations constituting the iconographic cataloging phase. On the other hand, the orography and the urban layout three-dimensional modeling, where the views of 
the travelers are inserted.

These new images pointing to a further level of comparison in which the digital representation allows to synthesize analytically the essential elements of the context, avoiding figurative interferences and obtaining graphic elaborations capable of returning new imaginative suggestions.

This narration process through hybridization of images, in time and space, finds a conceptual correspondence in that "truth-saying" inquiry faced by Foucault, which states «the dual determination of psykhe as correlated with the parresiastic truth-saying and èthos as a goal of parresiastic practice implies that parrēsia, while organizing around the principle of truth-saying, is now embodied in a set of operations allowing the veridiction to induce in the soul several effects of transformation.» ${ }^{8}$

Likewise, the search for a relocation of the architectural artifact of the Cathedral leads to the elaboration of representations that, through graphic and digital interdependence and imaginary parallel, create new operations and induce "transformation effects" of the drawing latent of that "truth-saying" principle, to say it with Focault, inseparably linked to the interpretative attitude of the observer.

\section{Literature Review}

The research activity started from the iconographic finding of the Palermo's Cathedral, which is part of the UNESCO World Heritage Site.

In the first phase of the research some texts concerning the Cathedral of Palermo were consulted, through which it was possible to initiate a first filing that allowed systematizing the historical and graphic data of the iconographic representations catalogued. ${ }^{9}$

The subsequent cartographic research led to the identification of the key historical moments in the representation of the city and the territory from 1580, when the first plan of Palermo was drawn. ${ }^{10}$ The analyzed cartographies include a time span ranging from the 16th to the 19th centuries, to the representations of Gaetano Lossieux of $1818 .^{11}$ This iconographic study aimed to provide critical and analytical support to the development of digital, orographic and urban models, enabling the creation of views in which the historical data interfaces with the digital one, in order to make recognizable the relationship between Grand Tour drawings and $3 \mathrm{D}$ reconstructions.

8. Cf. M. Foucault, Il coraggio della verità. Il governo di sé e degli altri II. Corso al Collège de France (1984) (Milano: Feltrinelli Editore, 2016), 73.

9. D. Lo Faso Pietrasanta, Del Duomo Di Monreale E Di Altre Chiese Siculo Normanne (Palermo: Editore Tipografia Roberti, 1838); C. De Seta, M. A. Spadaro and S. Troisi, Palermo città d'arte. Guida ai monumenti di Palermo e Monreale (Palermo: Edizioni Ariete, 1998).

10. R. La Duca, Cartografia generale della città di Palermo e antiche carte della Sicilia (Napoli: Edizioni Scientifiche Italiane, 1975); De Seta and Di Mauro, Le città nella storia d'Italia, 1981.

11. La Duca, Cartografia generale della città di Palermo e antiche carte della Sicilia, 1975; De Seta and Di Mauro, Le città nella storia d'Italia, 1981; A. I. Lima, La crescita della città di Palermo nella pianta di Gaetano Lossieux (1818) (Palermo: S. F. Flaccovio Editore, 1979). 


\section{Methodology}

The cognitive telling of the Palermo's Cathedral, obtained through a graphic study of the paths that, in the various historical phases, provided multiple images. These ones depending on the addition and subtraction of volumes, voids, urban portions and soil transformations, keeping the scar of time in the construction of orographic sections and prospective views, highlight the role of perception in this changing trinomial urban plot-landscape-architectural artifacts.

After the cartographic finding stage, starting point for the three-dimensional reconstruction of Palermo follows the study of images made during the 18th and 19th centuries known as Grand Tour. During this period, travelers, writers, engravers and designers, driven by the curiosity of knowing the places in the Mediterranean where recognize the Greek or Byzantine traces, portrayed graphic and literary descriptions of many of the cities of southern Italy.

These two research stages converge in the development of digital perspectives and axonometric views through which the cartography highlights different historical moments, the way how the Cathedral of Palermo relate to the urban context and the privileged observation points of travelers who graphically recorded and handed down the building obtaining a sort of digital traveling diary.

Subsequently, a digitization activity in the territory of Palermo started with the objective of achieving a three-dimensional reference base for the construction of the urban scale model, of the town's historical and urban development.

The contour lines digitization at a 1:25.000 scale and later 3D modeling have been made by elaborating perspective and axonometric views of the urban layout inserted into the territory's morphology. This was made by selecting some of the territorial and urban elements considered most useful for the reading and real understanding of architectural and landscape aspect, thus obtaining a series of digital hybridizations between the representations told by the Grand Tour travelers and the virtual modeling of the various scales (Figure 17).

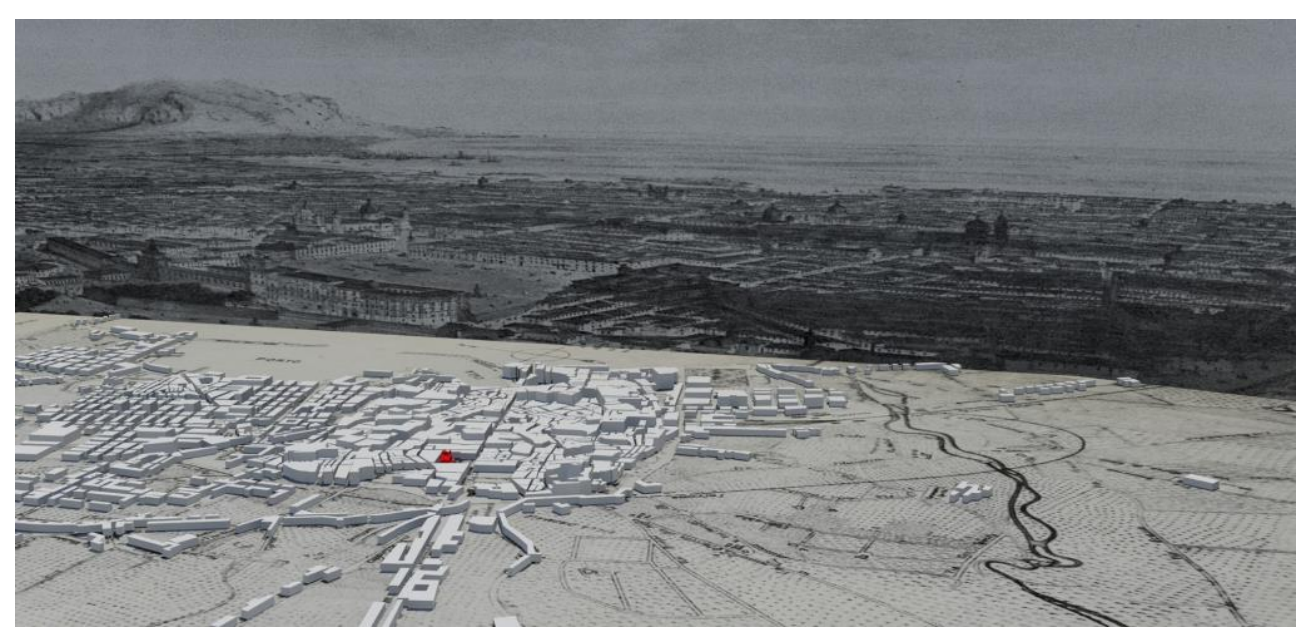

Figure 17. Digital Hybridizations between the Digital Model of the Historic Center of Palermo and the Lithography of 1844 Published in the Textbook of Étiennez Hippolyte

Source: Model and Digital Elaboration by S. Vattano. 
In this way, it was possible to highlight the Cathedral, showing its relationship not only with the orographic and landscape aspect, but also with the urban one.

This approach allowed to carry out a three-dimensional reconstruction of the territory of Palermo and the modeling of its urban center by proceeding to the digital telling of urban development through the elaboration of views taken from the model. The representations made by the travelers in these $3 \mathrm{D}$ models allow to understand more the relationship between the Cathedral and the mountainous curtain, natural background of the city and the sea (Figure 18).

The model at 1:10.000 scale with the addition of the Cathedral, along with a graphic reading of the orography, allowed highlighting the morphological and urban characteristics of the city.

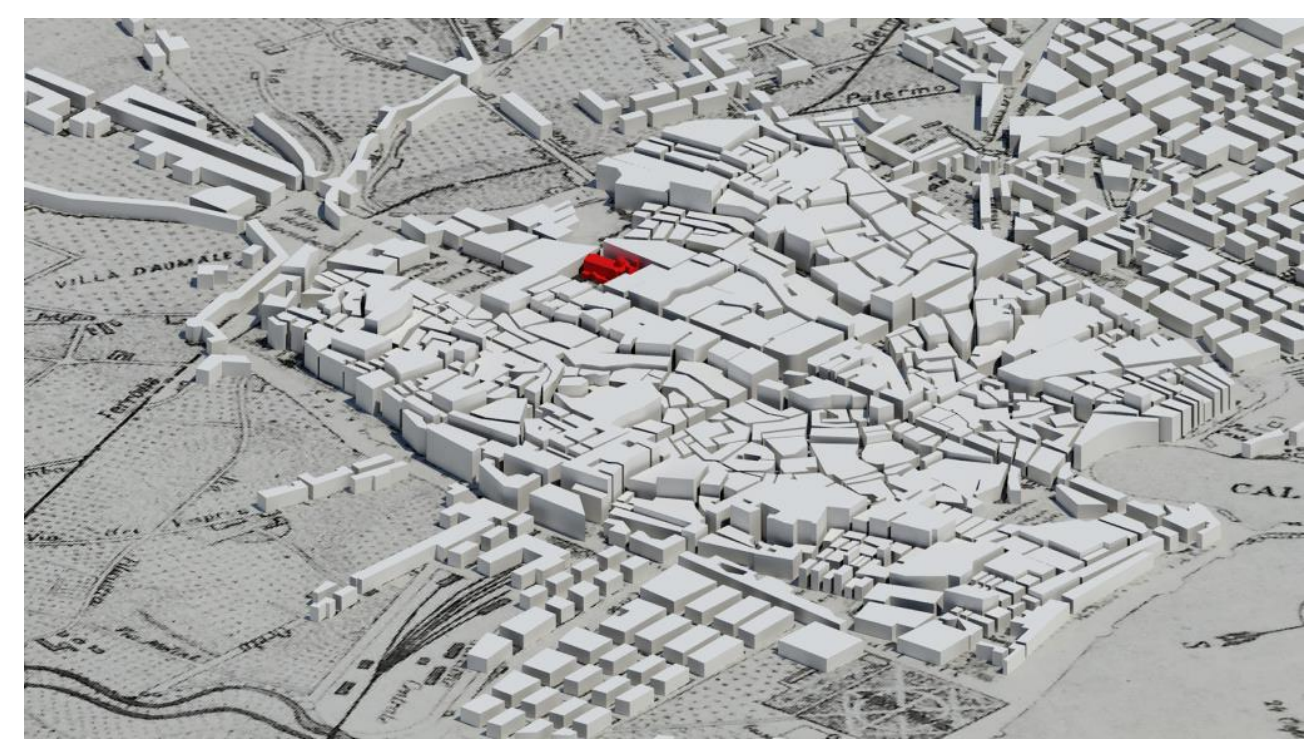

Figure 18. Digital Hybridizations between the Digital Model of the Historic Center of Palermo and the Cartography of Nineteenth Century

Source: Model and Digital Elaboration by S. Vattano.

The identification of the points of view chosen by travelers representing the city constitutes the stage of production of a "travel diary", which shows the itineraries and different ways of perceiving and interpreting the architectural body of the Cathedral in its relationship with the urban context. The produced images focus on the representation modes of the travelers who, while preferring the same observation points, traced different details from time to time, telling a previously assimilated and interpreted architecture, subsequently graphically returned according to a subjective and often imaginary perception that summarizes some of the configurations assumed by the Cathedral over time (Figure 19).

The representations from the urban model where the Cathedral's views are identified and inserted provide a graphic synthesis that collects images of a path towards the Cathedral. This methodology provided some of the possible configurations related to visual perception and recognition of the peculiar elements that characterize the architectural body in relation to the urban context. Historical cartography support facilitated chronological reconstruction, obtaining some images of what the relationship between the Cathedral and the traveling narrator 
was to be.

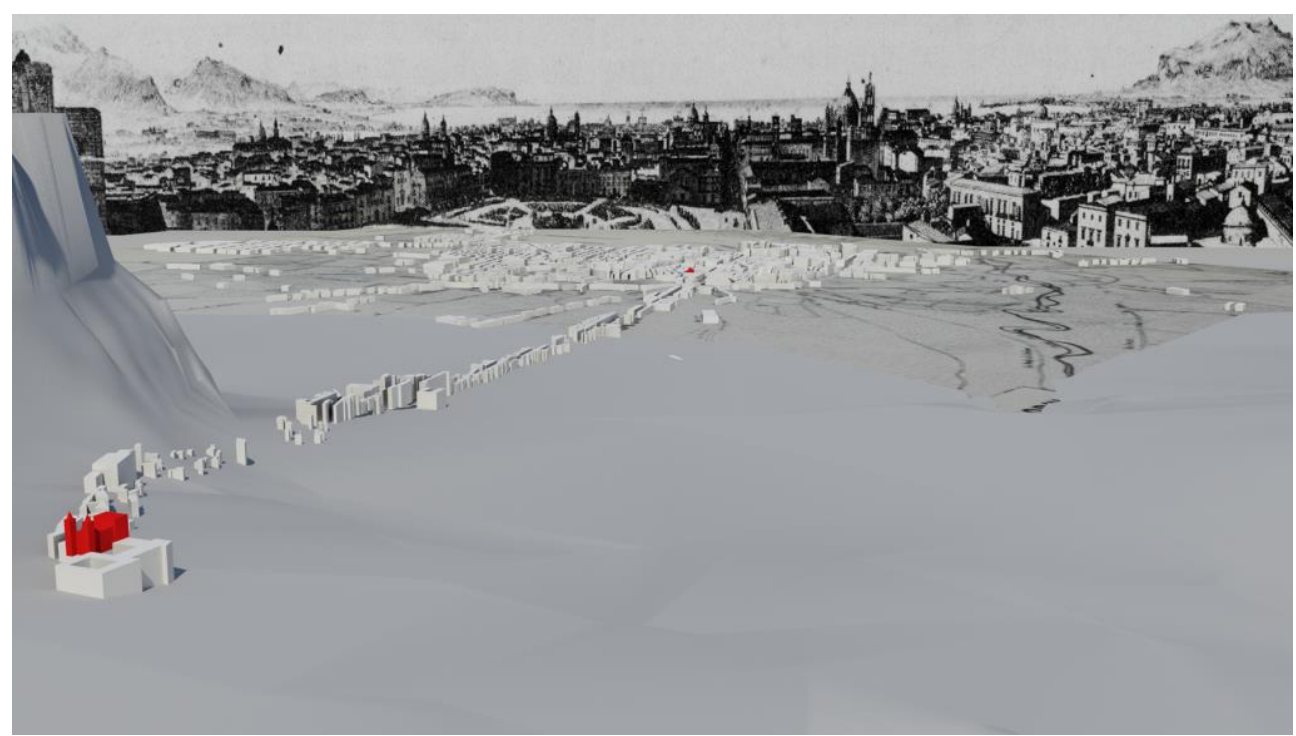

Figure 19. Digital Hybridizations between the Digital Model of the Historic Center of Palermo and the Bird's Eye Views Made by Travelers of the Nineteenth Century. The View Includes the Cathedral of Monreale and the Stardone Once Connecting the Two Centers

Source: Model and Digital Elaboration by S. Vattano.

\section{Conclusions}

Through this historical-graphic transversal study between historic cartography and digital reconstruction of the ground, it was possible to read those morphological characteristics that fostered urban changes over time, defining the physiognomy of the city of Palermo where the Cathedral recorded its formal transformations.

The elaboration of digital models, based on the interpretation of historical cartographies and the views of travelers portraying the ancient Panormo from the 16th to the 19th centuries, allowed to manage an inedited three-dimensional process of urban evolution through "stratifications" and "isolations" of the most significant historical configurations with the realization of images containing both the digital and traditional attribute of the drawing.

In this study, digital modeling and historical cartography have provided city images represented through mixed representation forms constituting a stratified graphic language centered on the relationship between the different historical periods and the modes of interpreting urban spaces. Readings and transformations of signs configured in digital hybridizations filtered through the eye of the interpretation. 


\section{Bibliography}

Amari, M. Biblioteca arabo-sicula [Arab-Sicilian Library.] Torino e Roma: 1880-1881, I.

Calamia F. and A. Catalano. La cattedrale di Palermo. Otto secoli di vicende architettoniche [The cathedral of Palermo. Eight centuries of architectural events.] Palermo: Epos, 1981.

De Seta, C., and L. Di Mauro. Le città nella storia d'Italia [Cities in the history of Italy]. Bari: Editori Laterza, 1981.

, M. A. Spadaro and S. Troisi. Palermo città d'arte. Guida ai monumenti di Palermo e Monreale [Palermo city of art. Guide to the monuments of Palermo and Monreale.] Palermo: Edizioni Ariete, 1998.

Foucault, M. Il coraggio della verità. Il governo di sé e degli altri II. Corso al Collège de France (1984) [The courage of the truth. The government of oneself and of others II. Course at the Collège de France (1984.)] Milano: Feltrinelli Editore, 2016.

La Duca, R. Cartografia generale della città di Palermo e antiche carte della Sicilia [General mapping of the city of Palermo and ancient maps of Sicily.] Napoli: Edizioni Scientifiche Italiane, 1975.

Lima, A. I. La crescita della città di Palermo nella pianta di Gaetano Lossieux (1818) [The growth of the city of Palermo in the plan of Gaetano Lossieux (1818.)] Palermo: S. F. Flaccovio Editore, 1979.

Lo Faso Pietrasanta, D. Del Duomo Di Monreale E Di Altre Chiese Siculo Normanne [Of The Cathedral Of Monreale And Of Other Churches Siculo Normanne.] Palermo: Editore Tipografia Roberti, 1838. 